\title{
Two new bisindole alkaloids from Tabernaemontana macrocarpa Jack
}

\author{
Puteri Amelia ${ }^{1,2} \cdot$ Alfarius Eko Nugroho $^{1} \cdot$ Yusuke Hirasawa ${ }^{1} \cdot$ Toshio Kaneda $^{1} \cdot$ Takahiro Tougan $^{3} \cdot$ Toshihiro Horii $^{4}$. \\ Hiroshi Morita ${ }^{1}$
}

Received: 12 January 2021 / Accepted: 28 March 2021 / Published online: 6 April 2021

(C) The Japanese Society of Pharmacognosy 2021

\begin{abstract}
Two new bisindole alkaloids, bisnaecarpamines A (1) and B (2), possessing a vobasine-sarpagine type skeleton were isolated from the bark of Tabernaemontana macrocarpa Jack. Their structures were elucidated by extensive spectroscopic methods and chemical correlation. The absolute configurations of compounds $\mathbf{1}$ and $\mathbf{2}$ were established using TDDFT-ECD calculation of the selected isomers. Bisnaecarpamine A exhibited potent antimalarial activity against Plasmodium falciparum 3D7 strain with $\mathrm{IC}_{50}$ value of $28.8 \mu \mathrm{M}$.
\end{abstract}

\section{Graphic abstract}

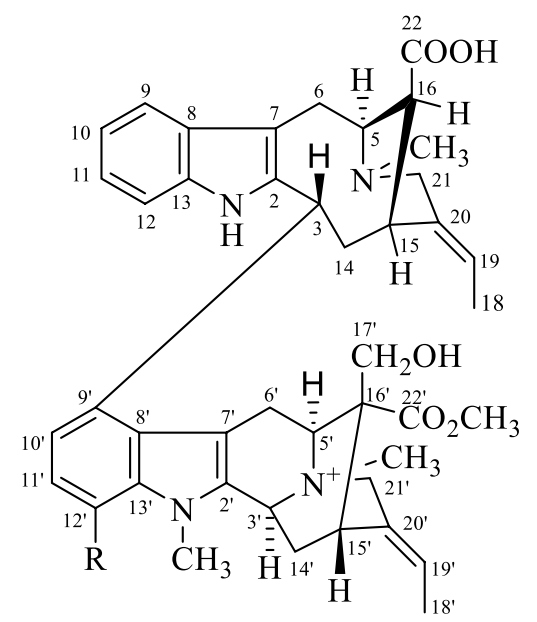

bisnaecarpamine A (1)

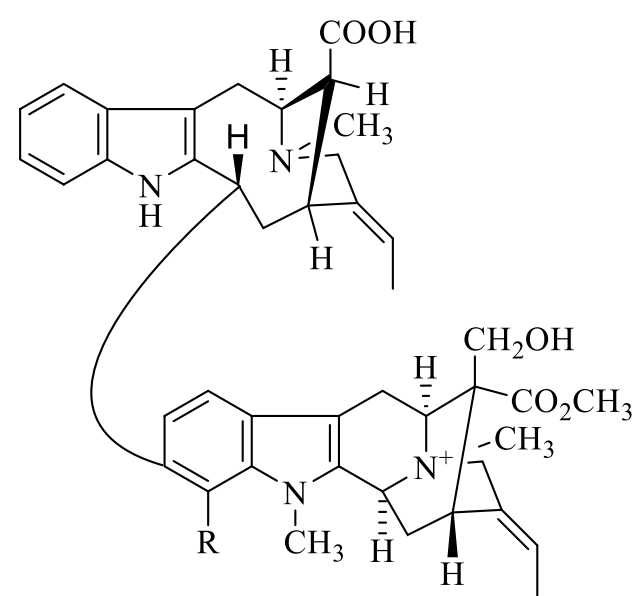

bisnaecarpamine B (2)

Keywords Bisindole alkaloid · Tabernaemontana macrocarpa Jack · Antimalarial activity

Hiroshi Morita

moritah@hoshi.ac.jp

1 Faculty of Pharmaceutical Sciences, Hoshi University, Ebara 2-4-41 Shinagawa-ku, Tokyo 142-8501, Japan

2 Department of Pharmacy, Faculty of Health Sciences, Universitas Islam Negeri Syarif Hidayatullah Jakarta, Jl. Kertamukti No 5, Pisangan Ciputat, South Tangerang, Indonesia
3 Research Center for Infectious Disease Control, Research Institute for Microbial Diseases, Osaka University, 3-1 Yamadaoka, Suita, Osaka 565-0871, Japan

4 Department of Malaria Vaccine Development, Research Institute for Microbial Diseases, Osaka University, 3-1 Yamadaoka, Suita, Osaka 565-0871, Japan 


\section{Introduction}

Plants of the genus Tabernaemontana are known as a storehouse of indole and bisindole alkaloids. Bisindole alkaloids are consisting of two different or identical monomeric indole alkaloid units with a $\mathrm{C}-\mathrm{N}, \mathrm{C}-\mathrm{O}-\mathrm{C}$, or $\mathrm{C}-\mathrm{C}$ bond [1]. Interestingly, some of the bisindole alkaloids showed cytotoxicity rather than those with monomeric units [2-4]. Various indole alkaloids that exhibited diverse molecular skeleton and significant diverse bioactivity have been reported from our laboratory [5-14].

Tabernaemontana macrocarpa Jack is distributed in Indonesia, Malaysia, Brunei, and the Philippines. Traditionally, the exudate of this plant has been used in Borneo, Indonesia, for the treatment of dental disease, herpes, and eczema, while the wood is used for simple construction work [15, 16]. Our previous chemical research of this plant revealed two sarpagine type indole alkaloids together with a known bisindole alkaloid, 16-demethoxycarbonylvoacamine, and their antimalarial activity [17]. The results showed only the dimeric alkaloid, 16-demethoxycarbonylvoacamine, showed moderate in vitro antimalarial activity with $\mathrm{IC}_{50}$ value of $28.8 \mu \mathrm{M}$ [17]. In order to searching for more bioactive bisindole alkaloids from this plant, the chemical investigation on the bark of T. macrocarpa Jack was carried out and two new bisindole alkaloids, bisnaecarpamines A and B (1 and 2) (Fig. 1), were isolated. Herein are reported the isolation, structure determination, and antimalarial activity of bisnaecarpamines A and B (1 and 2).

\section{Results and discussions}

\section{Structure elucidation of 1 and 2}

Compound $\mathbf{1}$ was obtained as an optically active yellowish amorphous solid, $[\alpha]_{\mathrm{D}}^{24}-10(c 1.0, \mathrm{MeOH})$. The IR absorptions implied the presence of hydroxy $\left(3395 \mathrm{~cm}^{-1}\right)$ and ester carbonyl $\left(1726 \mathrm{~cm}^{-1}\right)$ functionalities, while the UV absorption bands at $\lambda_{\max } 225$ and $271 \mathrm{~nm}$ indicated an indole chromophore [18]. The ESIMS (pos.) of 1 showed a molecular ion peak at $\mathrm{m} / \mathrm{z} 733[\mathrm{M}]^{+}$and the molecular formula was established as $\mathrm{C}_{44} \mathrm{H}_{53} \mathrm{~N}_{4} \mathrm{O}_{6}$ from HRESIMS. Analysis of the ${ }^{1} \mathrm{H}$ and ${ }^{13} \mathrm{C}$ NMR data (Table 1) and the heteronuclear single-quantum correlation (HSQC) spectrum of 1 revealed the presence of seven $\mathrm{sp}^{3}$ methines, seven $\mathrm{sp}^{3}$ methylenes, seven methyls, eight $\mathrm{sp}^{2}$ methines, one $\mathrm{sp}^{3}$ quaternary carbon, and $14 \mathrm{sp}^{2}$ quaternary carbons.

The gross structure of $\mathbf{1}$ was deduced from analyses of the 2D NMR data, including the ${ }^{1} \mathrm{H}-{ }^{1} \mathrm{H}$ correlation spectroscopy (COSY), HSQC, and heteronuclear multiple-bond correlation (HMBC) spectra in methanol- $d_{4}$ (Fig. 2). The ${ }^{1} \mathrm{H}-{ }^{1} \mathrm{H}$ COSY and HSQC spectra revealed connectivity of seven partial structures a (C-9-C-12), b (C-3, C-14-C-16, C-5-C6), c (C-18-C-19), d (C-10'-C-11'), e (C-5'-C-6'), f (C-3', $\left.\mathrm{C}-14^{\prime}-\mathrm{C}-15^{\prime}\right)$, and $\mathbf{g}\left(\mathrm{C}-18^{\prime}-\mathrm{C}-19^{\prime}\right)$. These partial structures were classified into two units, A and B, as shown in Fig. 2.

In unit $\mathrm{A}$, the HMBC correlations of $\mathrm{H}-6\left(\delta_{\mathrm{H}} 3.60\right)$ and $\mathrm{H}-12\left(\delta_{\mathrm{H}} 7.11\right)$ to $\mathrm{C}-8\left(\delta_{\mathrm{C}} 130.9\right)$, and H-9 $\left(\delta_{\mathrm{H}} 7.54\right)$ to $\mathrm{C}-7$ $\left(\delta_{\mathrm{C}} 109.9\right)$ and $\mathrm{C}-13\left(\delta_{\mathrm{C}} 137.9\right)$ revealed the attachment of partial structure a as part of indole ring, while the HMBC correlations of $\mathrm{H}-6 \mathrm{~b}$ to $\mathrm{C}-8, \mathrm{C}-2\left(\delta_{\mathrm{C}} 138.3\right)$ and $\mathrm{C}-7, \mathrm{H}-3$

Fig. 1 Structures of 1-2

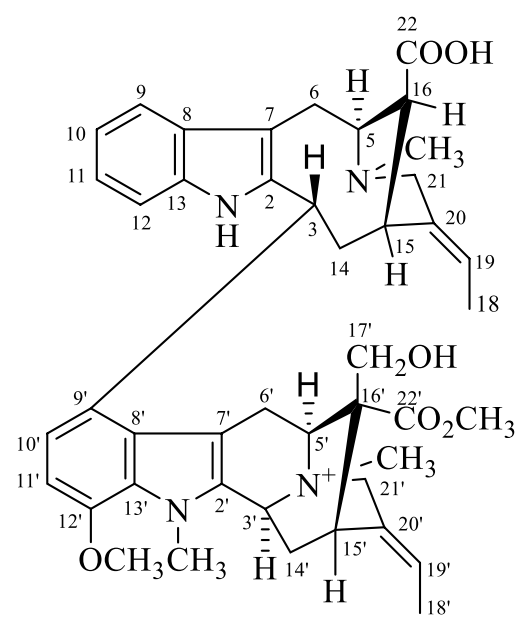

bisnaecarpamine A (1)

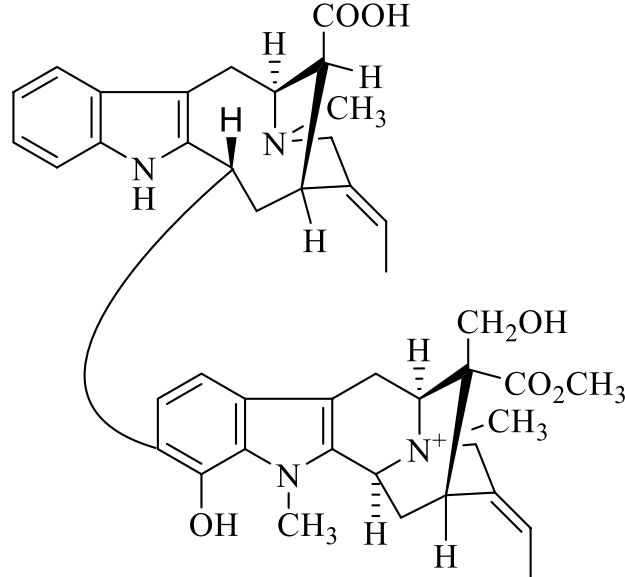

bisnaecarpamine B (2) 
Table $1{ }^{1} \mathrm{H}$ and ${ }^{13} \mathrm{C}$ NMR data of 1 and 2 in $\mathrm{CD}_{3} \mathrm{OD}^{\mathrm{a}}$

\begin{tabular}{|c|c|c|c|c|}
\hline \multirow[t]{2}{*}{ No } & \multicolumn{2}{|l|}{1} & \multicolumn{2}{|l|}{2} \\
\hline & $\delta_{\mathrm{H}}(J, \mathrm{~Hz})$ & $\delta_{\mathrm{C}}$ & $\delta_{\mathrm{H}}(J, \mathrm{~Hz})$ & $\delta_{\mathrm{C}}$ \\
\hline 2 & & $138.3^{\mathrm{b}}$ & & $133.5^{\mathrm{b}}$ \\
\hline 3 & $5.20(1 \mathrm{H}, \mathrm{dd}, 13.1,3.0)$ & 41.1 & $5.16(1 \mathrm{H}, \mathrm{brd}, 10.1)$ & 38.5 \\
\hline 5 & $4.10(1 \mathrm{H}, \mathrm{m})$ & 54.6 & $4.00(1 \mathrm{H}, \mathrm{m})$ & 61.0 \\
\hline $6 a$ & $3.37(1 \mathrm{H}, \mathrm{dd}, 11.1,8.1)$ & $20.5^{\mathrm{b}}$ & $3.31(1 \mathrm{H}, \mathrm{m})$ & $20.5^{\mathrm{b}}$ \\
\hline $6 \mathrm{~b}$ & $3.60(1 \mathrm{H}, \mathrm{br} \mathrm{d}, 11.1)$ & & $3.55(1 \mathrm{H}, \mathrm{br} d, 10.9)$ & \\
\hline 7 & & $109.9^{\mathrm{b}}$ & & $103.5^{\mathrm{b}}$ \\
\hline 8 & & $130.9^{\mathrm{b}}$ & & 130.9 \\
\hline 9 & $7.54(1 \mathrm{H}$, br d, 7.7$)$ & 118.4 & $7.52(1 \mathrm{H}, \mathrm{d}, 8.3)$ & 118.3 \\
\hline 10 & $7.01(1 \mathrm{H}, \mathrm{t}, 7.7)$ & 119.6 & $6.99(1 \mathrm{H}, \mathrm{m})$ & 119.5 \\
\hline 11 & $7.02(1 \mathrm{H}, \mathrm{t}, 7.7)$ & $122.5^{\mathrm{b}}$ & $7.00(1 \mathrm{H}, \mathrm{m})$ & $122.3^{\mathrm{b}}$ \\
\hline 12 & $7.11(1 \mathrm{H}$, br d, 7.7$)$ & 111.0 & $7.09(1 \mathrm{H}, \mathrm{m})$ & $110.0^{\mathrm{b}}$ \\
\hline 13 & & 137.9 & & 138.3 \\
\hline $14 \mathrm{a}$ & $1.91(1 \mathrm{H}, \mathrm{ddd}, 15.9,6.6,3.0)$ & 39.7 & $1.91(1 \mathrm{H}, \mathrm{m})$ & 39.4 \\
\hline $14 \mathrm{~b}$ & $2.68(1 \mathrm{H}, \mathrm{ddd}, 15.9,13.1,11.1)$ & & $2.59(1 \mathrm{H}, \mathrm{m})$ & \\
\hline 15 & $3.86(1 \mathrm{H}, \mathrm{br} \mathrm{d}, 11.1)$ & 34.2 & $3.81(1 \mathrm{H}, \mathrm{m})$ & 35.3 \\
\hline 16 & $2.71(1 \mathrm{H}, \mathrm{t}, 3.1)$ & 47.6 & $2.67(1 \mathrm{H}, \mathrm{t}, 3.7)$ & 48.3 \\
\hline 18 & $1.72(3 \mathrm{H}, \mathrm{d}, 6.9)$ & 12.7 & $1.68(3 \mathrm{H}, \mathrm{d}, 7.2)$ & 12.2 \\
\hline 19 & $5.44(1 \mathrm{H}, \mathrm{q}, 6.5)$ & $112.5^{\mathrm{b}}$ & $5.36(1 \mathrm{H}, \mathrm{q}, 7.2)$ & $119.5^{\mathrm{b}}$ \\
\hline 20 & & 137.9 & & 138.9 \\
\hline $21 \mathrm{a}$ & $3.10(1 \mathrm{H}$, br d, 13.5$)$ & 53.1 & $2.95(1 \mathrm{H}, \mathrm{brd}, 13.9)$ & 53.4 \\
\hline $21 \mathrm{~b}$ & $3.91(1 \mathrm{H}, \mathrm{br} \mathrm{d}, 13.5)$ & & $3.78(1 \mathrm{H}, \mathrm{m})$ & \\
\hline 22 & & 172.3 & & 172.2 \\
\hline $\mathrm{N} 1-\mathrm{H}$ & $8.55(1 \mathrm{H}, \mathrm{s})$ & & $8.55(1 \mathrm{H}, \mathrm{s})$ & \\
\hline N4-Me & $2.68(3 \mathrm{H}, \mathrm{s})$ & $42.0^{\mathrm{b}}$ & $2.58(3 \mathrm{H}, \mathrm{s})$ & 42.3 \\
\hline $2^{\prime}$ & & $133.3^{\mathrm{b}}$ & & $133.5^{\mathrm{b}}$ \\
\hline $3^{\prime}$ & $5.13(1 \mathrm{H}$, br d, 10.1$)$ & $59.5^{\mathrm{b}}$ & $5.07(1 \mathrm{H}, \mathrm{brd}, 10.6)$ & 59.4 \\
\hline $5^{\prime}$ & $5.14(1 \mathrm{H}, \mathrm{m})$ & $65.7^{\mathrm{b}}$ & $4.97(1 \mathrm{H}, \mathrm{m})$ & $65.8^{\mathrm{b}}$ \\
\hline $6^{\prime} \mathrm{a}$ & $3.68(1 \mathrm{H}, \mathrm{dd}, 17.5,6.1)$ & 22.6 & $3.22(1 \mathrm{H}, \mathrm{dd}, 14.6,7.1)$ & 20.0 \\
\hline $6^{\prime} \mathrm{b}$ & $4.59(1 \mathrm{H}, \mathrm{br} \mathrm{d}, 17.5)$ & & $3.73(1 \mathrm{H}, \mathrm{brd}, 14.6)$ & \\
\hline $7^{\prime}$ & & $103.0^{\mathrm{b}}$ & & $103.1^{\mathrm{b}}$ \\
\hline $8^{\prime}$ & & $125.6^{\mathrm{b}}$ & & $125.1^{\mathrm{b}}$ \\
\hline $9^{\prime}$ & & 133.0 & $7.15(1 \mathrm{H}, \mathrm{d}, 7.1)$ & 116.4 \\
\hline $10^{\prime}$ & $6.53(1 \mathrm{H}, \mathrm{d}, 8.1)$ & 121.1 & $6.68(1 \mathrm{H}, \mathrm{brd}, 7.1)$ & 122.3 \\
\hline $11^{\prime}$ & $6.59(1 \mathrm{H}, \mathrm{d}, 8.1)$ & 105.5 & & 121.7 \\
\hline $12^{\prime}$ & & $147.8^{\mathrm{b}}$ & & $149.2^{\mathrm{b}}$ \\
\hline $13^{\prime}$ & & $129.5^{\mathrm{b}}$ & & $129.4^{b}$ \\
\hline $14^{\prime} \mathrm{a}$ & $2.25(1 \mathrm{H}, \mathrm{br} \mathrm{d}, 13.6)$ & 28.8 & $2.13(1 \mathrm{H}, \mathrm{brd}, 11.9)$ & 29.3 \\
\hline $14^{\prime} \mathrm{b}$ & $2.55(1 \mathrm{H}, \mathrm{dd}, 13.6,10.1)$ & & $2.50(1 \mathrm{H}, \mathrm{m})$ & \\
\hline $15^{\prime}$ & $3.45(1 \mathrm{H}, \mathrm{br} \mathrm{s})$ & $31.4^{\mathrm{b}}$ & $3.38(1 \mathrm{H}, \mathrm{br} \mathrm{s})$ & $31.1^{\mathrm{b}}$ \\
\hline $16^{\prime}$ & & $56.8^{\mathrm{b}}$ & & $56.8^{\mathrm{b}}$ \\
\hline $17^{\prime} \mathrm{a}$ & $3.78(1 \mathrm{H}$, br d, 11.5$)$ & 64.3 & $3.58(1 \mathrm{H}, \mathrm{brd}, 10.9)$ & 63.9 \\
\hline $17^{\prime} \mathrm{b}$ & $3.96(1 \mathrm{H}, \mathrm{d}, 11.5)$ & & $3.70(1 \mathrm{H}, \mathrm{brd}, 10.9)$ & \\
\hline $18^{\prime}$ & $1.73(3 \mathrm{H}, \mathrm{d}, 6.9)$ & 12.9 & $1.70(3 \mathrm{H}, \mathrm{d}, 7.1)$ & 13.0 \\
\hline $19^{\prime}$ & $5.54(1 \mathrm{H}, \mathrm{q}, 6.9)$ & $121.2^{\mathrm{b}}$ & $5.55(1 \mathrm{H}, \mathrm{q}, 7.1)$ & $121.0^{\mathrm{b}}$ \\
\hline $20^{\prime}$ & & 128.5 & & 128.6 \\
\hline $21^{\prime} \mathrm{a}$ & $4.39(1 \mathrm{H}, \mathrm{d}, 16.7)$ & 65.5 & $4.30(1 \mathrm{H}, \mathrm{d}, 15.3)$ & 65.8 \\
\hline $21^{\prime} \mathrm{b}$ & $4.43(1 \mathrm{H}, \mathrm{d}, 16.7)$ & & $4.38(1 \mathrm{H}, \mathrm{d}, 15.3)$ & \\
\hline 22 & & $173.9^{\mathrm{b}}$ & & $174.2^{\mathrm{b}}$ \\
\hline $\mathrm{N} 11^{\prime}-\mathrm{Me}$ & $3.98(3 \mathrm{H}, \mathrm{s})$ & 33.4 & $4.01(3 \mathrm{H}, \mathrm{s})$ & 32.2 \\
\hline $\mathrm{N} 4^{\prime}-\mathrm{Me}$ & $3.35(3 \mathrm{H}, \mathrm{s})$ & $49.9^{\mathrm{b}}$ & $3.17(3 \mathrm{H}, \mathrm{s})$ & $50.1^{\mathrm{b}}$ \\
\hline OMe-12' & $3.86(3 \mathrm{H}, \mathrm{s})$ & $56.1^{\mathrm{b}}$ & & \\
\hline OMe-22' & $3.82(3 \mathrm{H}, \mathrm{s})$ & 53.6 & $3.75(3 \mathrm{H}, \mathrm{s})$ & $53.4^{\mathrm{b}}$ \\
\hline
\end{tabular}

${ }^{\mathrm{a} 1} \mathrm{H}$ NMR spectrum was measured on a $600 \mathrm{MHz}$ spectrometer, while ${ }^{13} \mathrm{C}$ NMR spectrum was measured on a $150-\mathrm{MHz}$ spectrometer

${ }^{\mathrm{b}}$ The chemical shift was deduced from 2D NMR 
Fig. 2 2D NMR correlations of bisnaecarpamine A (1)

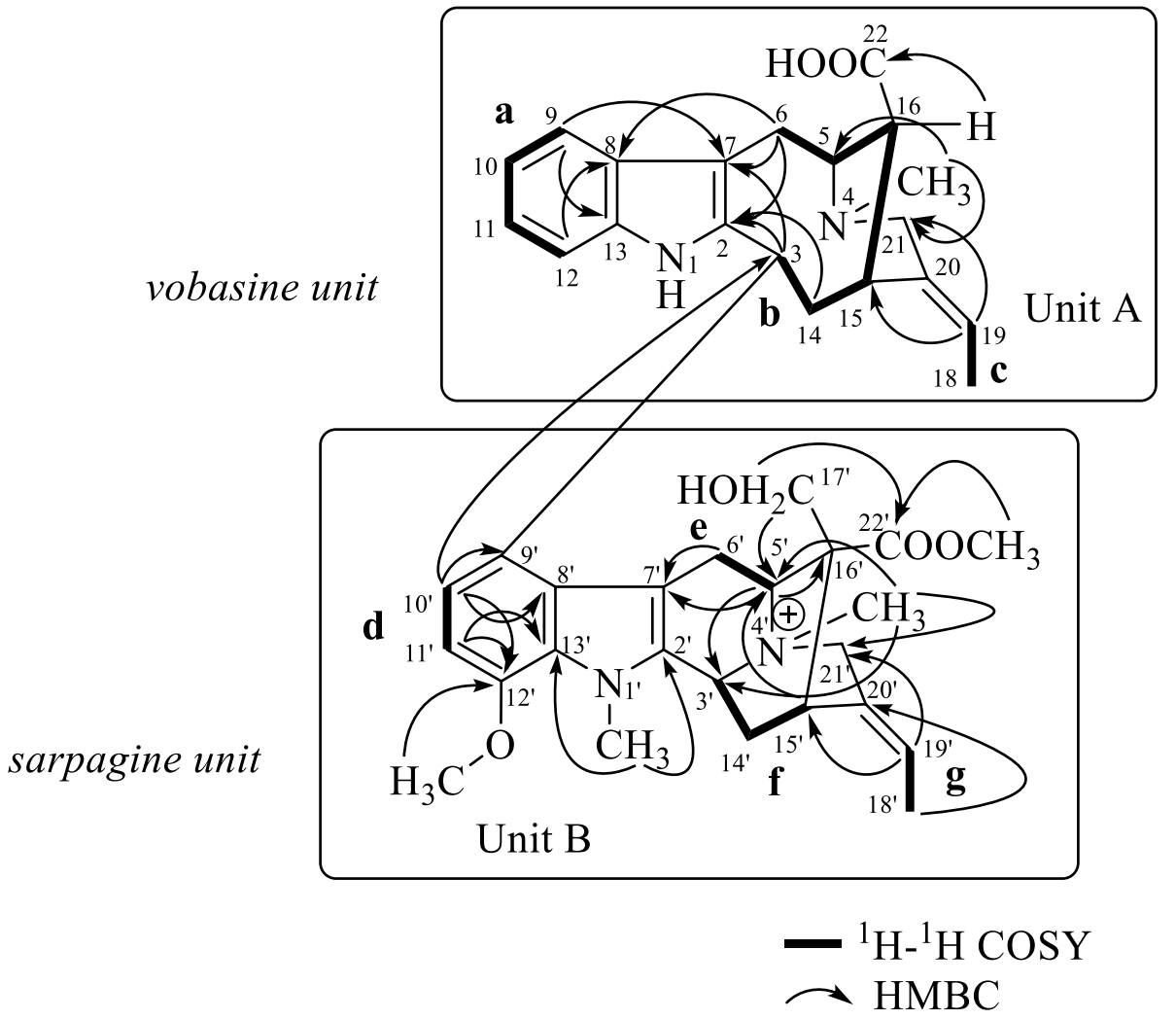

as shown in the Fig. 2, revealing a sarpagine-type skeleton. Finally, the linkage between C-3 at unit A and C-9' at unit B was provided by the HMBC correlation of $\mathrm{H}-10^{\prime}$ to $\mathrm{C}-3\left(\delta_{\mathrm{C}}\right.$ 41.1). Thus, the planar structure of bisnaecarpamine $A$ was assigned as shown to be in Fig. 2.

\section{Stereochemistry of bisnaecarpamine A (1)}

The stereochemistry of each monoterpene indole unit in $\mathbf{1}$ was assigned by rotating-frame Overhauser effect spectroscopy (ROESY) correlations as shown in the computer-generated 3D drawing (Fig. 3). In unit A, the ROESY correlations of $\mathrm{H}-3 / \mathrm{H}-15\left(\delta_{\mathrm{H}} 3.86\right)$ and $\mathrm{H}-14 \mathrm{a}\left(\delta_{\mathrm{H}} 1.91\right)$ suggested that those three protons were in the same plane and the ROESY correlations of $\mathrm{H}-15 / \mathrm{H}_{3}-18\left(\delta_{\mathrm{H}} 1.72\right)$ and $\mathrm{H}-19 / \mathrm{H}-21 \mathrm{a}\left(\delta_{\mathrm{H}}\right.$ 3.10) established the $E$-configuration of the ethylidene side chain. The relative configuration of C-16 could not assign by ROESY because there was no ROESY correlation of H-3/H-16. Treatment of 1 using trimethylsilyldiazomethane $\left(\mathrm{TMSCHN}_{2}\right)$ gave the methyl ester derivative of $\mathbf{1}$. The configuration of C-16 was proven to be $S *$ by the highly shielded methyl chemical shift $(2.62 \mathrm{ppm})$ of this derivative, which can be explained by the anisotropic effect of the indole ring [21]. While in unit $\mathrm{B}$, the ROESY correlations of $\mathrm{H}-3 / \mathrm{H}-21^{\prime} \mathrm{a}\left(\delta_{\mathrm{H}} 4.39\right)$ suggested that $\mathrm{H}-3^{\prime}\left(\delta_{\mathrm{H}} 5.13\right)$ and $\mathrm{H}-21^{\prime} \mathrm{a}$ were in the same plane and the correlation of H-6'a to $N-4$ ' suggested that H-6'a was $\alpha$-oriented. Furthermore, the 


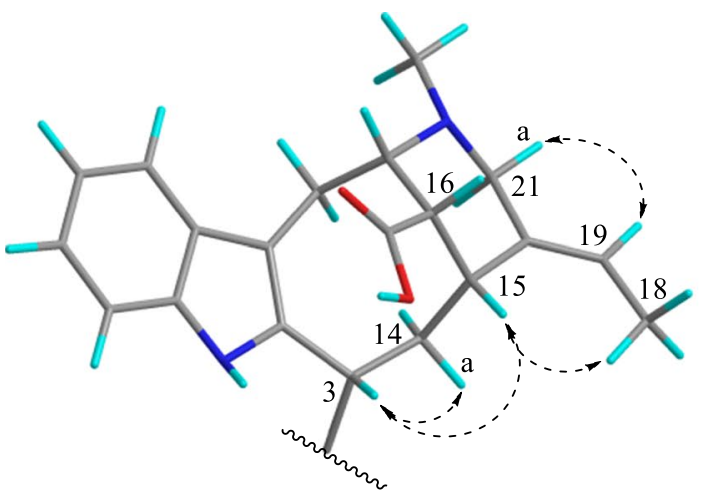

Unit A

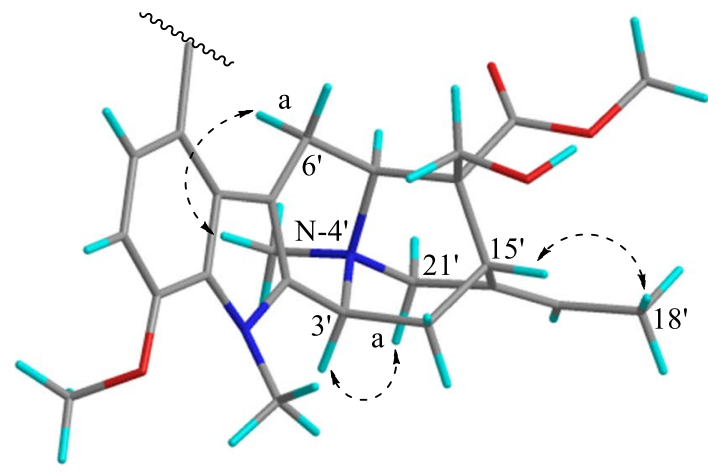

Unit B

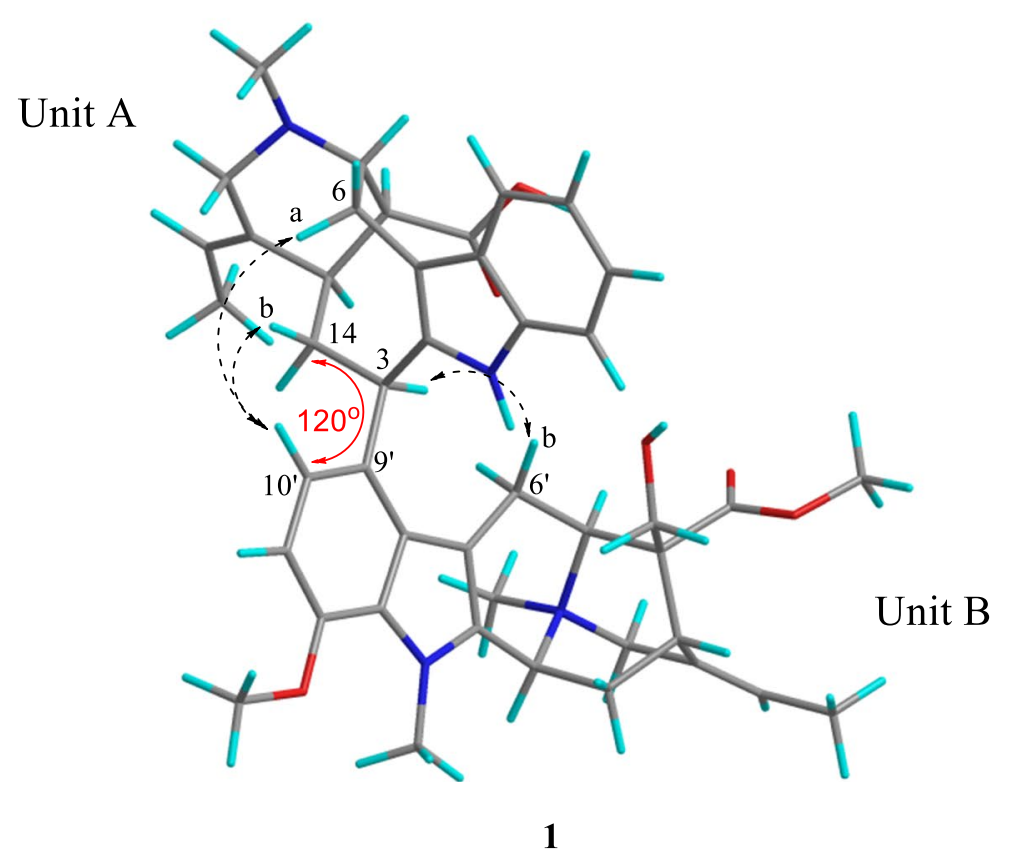

Fig. 3 Selected ROESY correlations and conformation of bisnaecarpamine A (1)

E-configuration of the ethylidene side chain was confirmed by the ROESY correlations of $\mathrm{H}-15^{\prime}\left(\delta_{\mathrm{H}} 3.45\right) / \mathrm{H}_{3}-18^{\prime}$.

The relation between units $\mathrm{A}$ and $\mathrm{B}$ of $\mathbf{1}$ was deduced from the ROESY correlations of H-6a and $\mathrm{H}-14 \mathrm{~b} / \mathrm{H}-10^{\prime}\left(\delta_{\mathrm{H}}\right.$ $6.53)$ and $H-3 / H-6 ' b\left(\delta_{H} 4.59\right)$ that suggested the relative configuration of $\mathbf{1}$ was as shown in Fig. 3.

Finally, the conformation of 1 through the C-3-C-9' bond was investigated by using molecular mechanics calculations [22]. The global minimum obtained through Monte Carlo conformational search [22] indicated the dihedral angle of C-14-C-3-C-9'-C-10' is ca. $120^{\circ}$ (Fig. 3) and consistent with the conformer suggested by the observed ROESY correlations of H-6a and H-14b/H-10' and H-3/H-6'b.

The absolute configuration of $\mathbf{1}$ was then assigned by comparing the experimental CD spectrum and the calculated CD spectrum as shown in Fig. 4. CD calculation was performed by Turbomole 7.1 [23] using RI-TD-DFTB3LYP/SVPD level of theory on RI-DFT-B3LYP/SVP optimized geometries. The experimental CD spectrum show similar CD pattern compared to calculated CD spectrum. Therefore, the absolute configuration of $\mathbf{1}$ was proposed as shown in Fig. 1.

Compound $\mathbf{2}$ was isolated as an optically active brownish amorphous solid $[\alpha]_{\mathrm{D}}^{25}$ : $-53(c 1.0, \mathrm{MeOH})$. The ESIMS (pos) showed a molecular ion peak at m/z $719[\mathrm{M}]+$. The IR absorptions implied the presence of hydroxy $\left(3383 \mathrm{~cm}^{-1}\right)$ and ester carbonyl $\left(1727 \mathrm{~cm}^{-1}\right)$ functionalities, while the UV absorption bands at $\lambda_{\max } 225$ and $287 \mathrm{~nm}$ indicated an indole chromophore [18]. The molecular formula $\mathrm{C}_{43} \mathrm{H}_{51} \mathrm{~N}_{4} \mathrm{O}_{6}$ was established by HRESIMS [m/z $719.3821[\mathrm{M}]^{+}$, $\Delta+2.1 \mathrm{mmu}$. The ${ }^{13} \mathrm{C}$ NMR data revealed the presence of seven $\mathrm{sp}^{3}$ methines, seven $\mathrm{sp}^{3}$ methylenes, six methyls, 

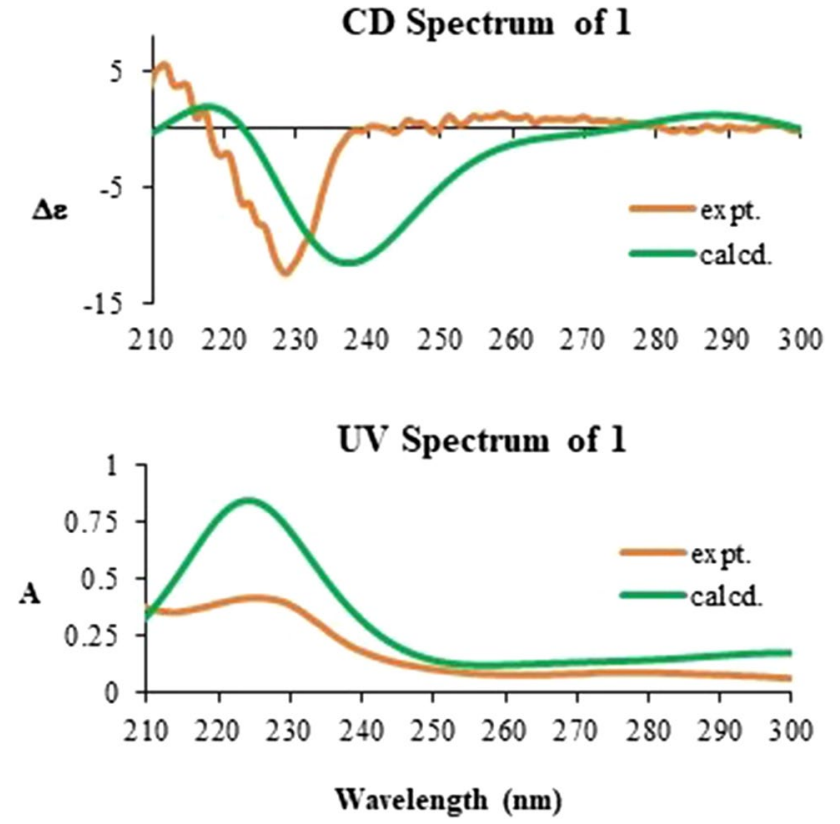

Fig. $4 \mathrm{CD}$ and UV spectra of bisnaecarpamine A (1)

eight $\mathrm{sp}^{2}$ methines, one $\mathrm{sp}^{3}$ quaternary carbon, and $14 \mathrm{sp}^{2}$ quaternary carbons (Table 1 ).

The NMR spectra of $\mathbf{1}$ and $\mathbf{2}$ exhibited similar resonances differ in the linkage position of the two monomer units and the presence of a hydroxy group in $\mathbf{2}$ was suggested instead of a singlet methyl signal $\left(\delta_{\mathrm{H}} 3.86\right)$ of methoxy group at $\mathrm{C}-12$ ' in 1. Further analysis of the two-dimensional NMR data $\left({ }^{1} \mathrm{H}-{ }^{1} \mathrm{H}\right.$ COSY, HSQC, and $\mathrm{HMBC}$ spectra in $\left.\mathrm{CD}_{3} \mathrm{OD}\right)$ of 2 revealed that it was also composed of a vobasine and sarpagine indole alkaloid as well as $\mathbf{1}$. The ROESY correlation of $\mathrm{H}-10^{\prime} / \mathrm{H}-3$ and $\mathrm{H}-10^{\prime} / \mathrm{H}-14 \mathrm{~b}$ in Fig. 5, and the carbon chemical shift of $\mathrm{C}-10^{\prime}\left(\delta_{\mathrm{C}} 121.1\right), \mathrm{C}-11^{\prime}\left(\delta_{\mathrm{C}} 105.5\right)$, and $\mathrm{C}-12^{\prime}\left(\delta_{\mathrm{C}} 147.8\right)$ suggested that the linkage between units $\mathrm{A}$ and B in 2 was C-3-C-11' instead of C-3-C-9' in 1.

The stereochemistry of each monoterpene indole unit of $\mathbf{2}$ was assigned by ROESY correlations as shown in the Fig. 5 . The ROESY correlations of $\mathrm{H}-15 / \mathrm{H}_{3}-18$ and $\mathrm{H}-15^{\prime} / \mathrm{H}_{3}-18^{\prime}$ established the $E$-configuration of the both ethylidene side chains. The $\beta$-orientation of $\mathrm{H}-3$ and the $\alpha$-orientation of $\mathrm{H}-3^{\prime}$ was elucidated by the ROESY correlations of $\mathrm{H}-3 / \mathrm{H}-$ 15 and $\mathrm{H}-3^{\prime} / \mathrm{H}-21^{\prime} \mathrm{a}$, respectively. The configuration of C-16 was proven to be $S^{*}$ by the ROESY correlation of $\mathrm{H}-16 / \mathrm{H}-$ 21b. Analysis of the ROESY spectral data also suggested that $\mathbf{2}$ had similar relative configuration as in $\mathbf{1}$ for both unit $\mathrm{A}$ and $\mathrm{B}$.

The conformation of 2 through the C-3-C-11' bond was assigned by the ROESY correlations of $\mathrm{H}-3 / \mathrm{H}-10^{\prime}$ and $\mathrm{H}-\mathrm{9}^{\prime} /$ $\mathrm{H}-6$ 'b as shown in the Fig. 5. The difference in the linkage of units A and B in $\mathbf{1}$ and $\mathbf{2}$ resulted in the difference of their total conformation, i.e., compound $\mathbf{1}$ possessed a twist conformation (Fig. 3), while compound $\mathbf{2}$ adopted an extended conformation with dihedral angle of C-14-C-3-C-11'-C-10' is ca. $110^{\circ}$ (Fig. 5).

Furthermore, to define the absolute configuration of $\mathbf{2}$, the TDDFT-ECD method was applied on the global minimum of 2. The result showed that calculated CD spectrum displayed a good similarity to the experimental CD spectrum of $\mathbf{2}$ as shown in Fig. 6.

A plausible biogenetic pathway for bisnaecarpamines A and B (1 and $\mathbf{2})$ is proposed as shown in Fig. 7. Their structures consisting of a vobasine-sarpagine type skeleton might be generated through $\mathrm{C}-\mathrm{N}$ bond cleavage of a quaternary sarpagine-type alkaloid [20] followed by the introduction of another sarpagine-type alkaloid as a nucleophile. Nucleophilic attack to C-3 from C-9' in the sarpagine-type alkaloid formed bisnaecarpamine A (1) as shown in route $\mathbf{a}$, while bisnaecarpamine B (2) might be generated by an attack from C-11' as shown in route $\mathbf{b}$.

\section{Antimalarial activity}

We have reported that some bisindole alkaloids showed antimalarial activity $[5,7,17,24]$. Bisnaecarpamines A and B (1 and 2) were tested for the antimalarial activity against $P$. falciparum 3D7 strain. The result showed that 1 showed potent in vitro antimalarial activity [the half-maximal (50\%) inhibitory concentration $\left.\left(\mathrm{IC}_{50}\right)=4.60 \mu \mathrm{M}\right]$ while $2 \mathrm{did}$ not show activity even at $50 \mu \mathrm{M}$.

Compounds $\mathbf{1}$ and $\mathbf{2}$ have a different connection between units $\mathrm{A}$ and $\mathrm{B}$ causing them to take distinct conformations. The difference in conformations is one possible reason for the contrast in their antimalarial activity.

\section{Experimental section}

\section{General experimental procedures}

Optical rotations were measured on a JASCO DIP-1000 polarimeter. UV spectra were recorded on a Shimadzu UVmini-1240 spectrophotometer and IR spectra on a JASCO FT/IR-4100 spectrophotometer. High-resolution ESI MS were obtained on a LTQ Orbitrap XL (Thermo Scientific). ${ }^{1} \mathrm{H}$ and 2D NMR spectra were measured on $600 \mathrm{MHz}$ spectrometer at $300 \mathrm{~K}$, while ${ }^{13} \mathrm{C}$ NMR spectra were measured on a $150-\mathrm{MHz}$ spectrometer. The residual solvent peaks were used as internal standards $\left(\delta_{\mathrm{H}} 3.31\right.$ and $\delta_{\mathrm{C}} 49.0$ for $\mathrm{CD}_{3} \mathrm{OD}$ ). Standard pulse sequences were used for the $2 \mathrm{D}$ NMR experiments. Merck silica gel $60(40-63 \mu \mathrm{m})$, amino silica, and HP-20 were used for the column chromatography, and the separations were monitored by Merck silica gel 60 F254 or Merck amino silica gel F254 TLC plates. 


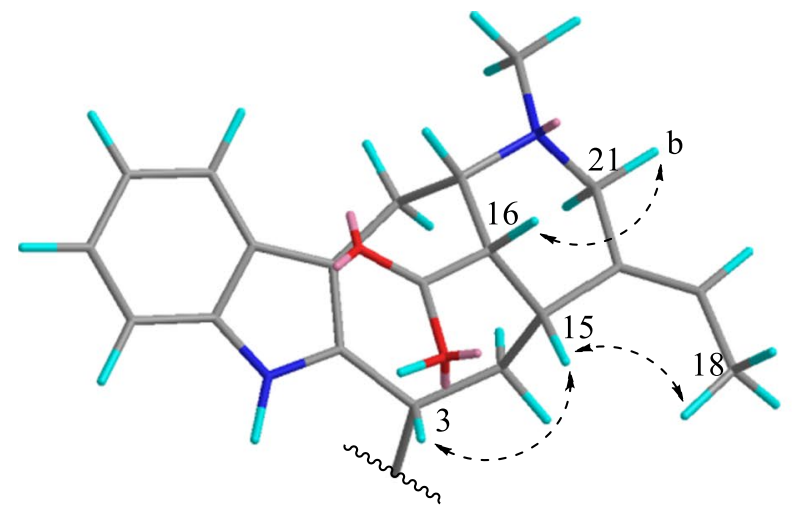

Unit A

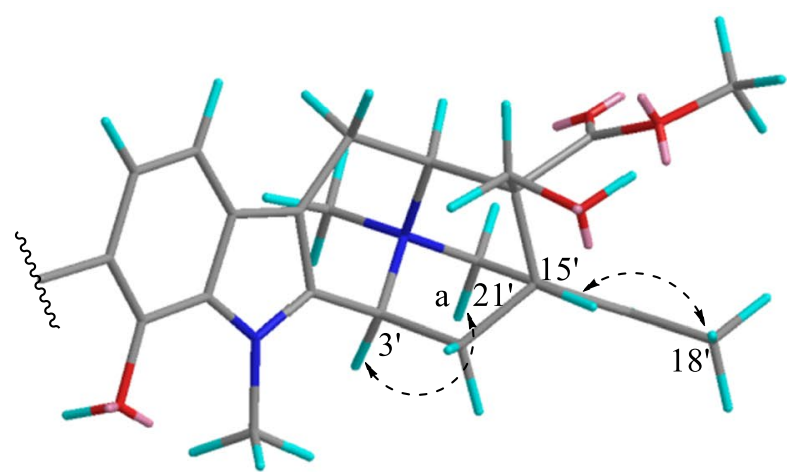

Unit B

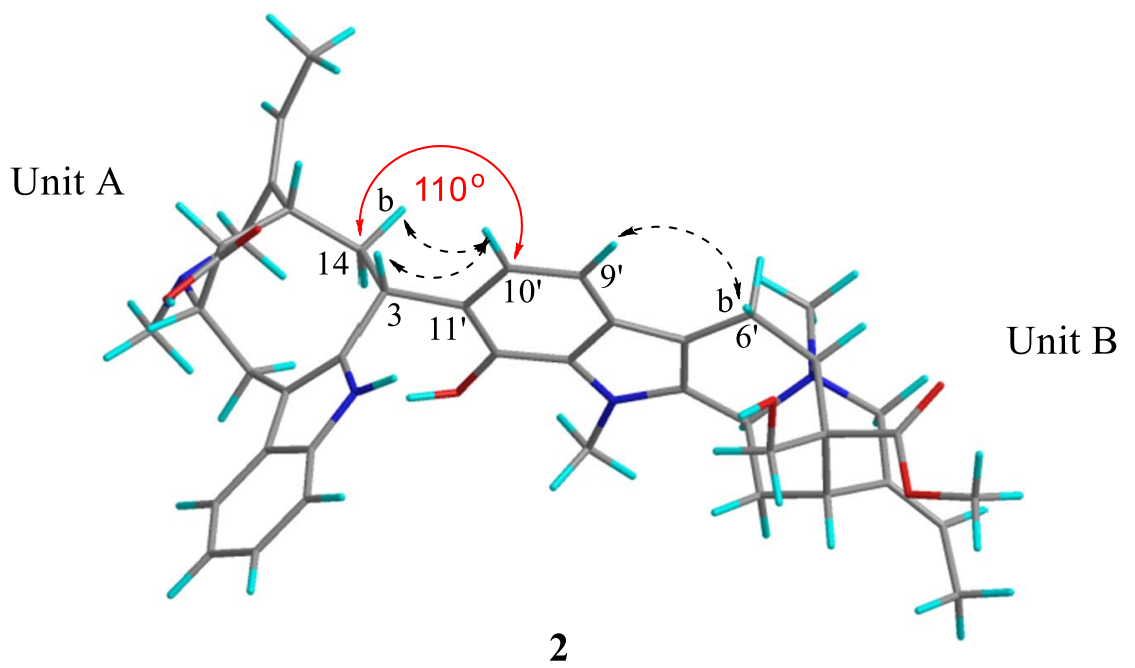

Fig. 5 Selected ROESY correlations and conformation of bisnaecarpamine B (2)

\section{Plant materials}

The barks of Tabernaemontana macrocarpa Jack were collected in June 2018 from Centre for Plant Conservation Botanic Gardens, Bogor, Indonesia. The GPS coordinates of the field site are $6^{\circ} 35^{\prime} 59.65^{\prime \prime} \mathrm{S}, 106^{\circ} 47^{\prime} 54.00^{\prime \prime} \mathrm{E}$. Authentication and identification of plant was carried out by Mr. Ikar Supriatna at Centre for Plant Conservation Botanic Gardens, Bogor, Indonesia.

\section{Extraction and isolation}

The barks of $T$. macrocarpa Jack (1520 g) were extracted with $\mathrm{MeOH}$, and part of the extract ( $8 \mathrm{~g}$ ) was treated with $3 \%$ tartaric acid ( $\mathrm{pH} 2)$, and then partitioned with EtOAc. The aqueous layer was treated with saturated $\mathrm{Na}_{2} \mathrm{CO}_{3}(\mathrm{aq})$ to $\mathrm{pH} 10$ and extracted with $\mathrm{CHCl}_{3}$ to give an alkaloidal fraction $(0.8 \mathrm{~g})$ and continued by partition with butanol to give $n$-butanol fraction $(1.6 \mathrm{~g})$. The $\mathrm{CHCl}_{3}$ fraction was subjected to a column chromatography over Sephadex
LH-20 and eluted with $\mathrm{CHCl}_{3} / \mathrm{MeOH}(1: 1, \mathrm{v} / \mathrm{v})$ to give 24 fractions. Separation of fraction $17(63 \mathrm{mg})$ by a silica gel column eluted with $n$-hexane/ethyl acetate (49:1-1:1, v/v) continued by $\mathrm{CHCl}_{3} /$ methanol (49:1-100\%), gave six fractions. The fourth eluted fraction was subjected to ODS HPLC (Cosmosil C18 MS-II, $5 \mu \mathrm{m}, 10 \times 250 \mathrm{~mm}$; eluent $24 \% \mathrm{CH}_{3} \mathrm{CN} / \mathrm{H}_{2} \mathrm{O}$; $0.1 \%$ TFA aq.; flow rate, $2.5 \mathrm{~mL} / \mathrm{min}$; $\mathrm{UV}$ detection at $254 \mathrm{~nm}$ ) to afford bisnaecarpamine A (1, $3.2 \mathrm{mg}, 0.00021 \%$, tR $13.1 \mathrm{~min}$ ) and bisnaecarpamine B $(2,4.1 \mathrm{mg}, 0.00027 \%$, tR $11.8 \mathrm{~min})$.

\section{Methyl esterification reaction}

The preparation of methyl esters from carboxylic acids can be achieved with trimethylsilyldiazomethane $\left(\mathrm{TMSCHN}_{2}\right)$ in methanolic benzene. Compound 1 (0.1 mg) was dissolved in $\mathrm{MeOH}(100 \mu \mathrm{l})$ and $\mathrm{TMSCHN}_{2}(50 \mu \mathrm{l})$ added. The reaction was easily monitored by the disappearance of the yellow color of $\mathrm{TMSCHN}_{2}$. The ${ }^{1} \mathrm{H}$ NMR of reaction product showed a methyl signal at $2.62 \mathrm{ppm}$. 

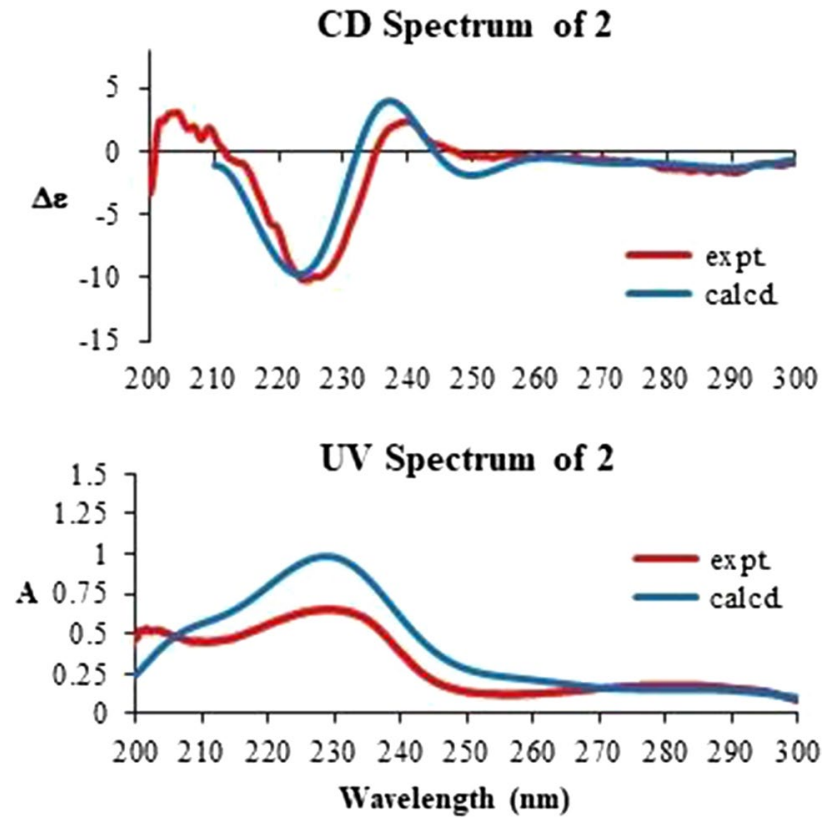

Fig. $6 \mathrm{CD}$ and UV spectra of bisnaecarpamine $\mathrm{B}(2) \mathrm{1}$ : $\mathrm{R}=\mathrm{OCH}_{3}$ 2: $\mathrm{R}=\mathrm{OH}$

\section{Parasite strain culture}

P. falciparum laboratory strain 3D7 was obtained from Prof. Masatsugu Kimura (Osaka City University, Osaka, Japan). For the assessment of antimalarial activity of the compounds in vitro, the parasites were cultured in Roswell Park Memorial Institute (RPMI) 1640 medium supplemented with $0.5 \mathrm{~g} / \mathrm{L}$ L-glutamine, $5.96 \mathrm{~g} / \mathrm{L}$ HEPES, $2 \mathrm{~g} / \mathrm{L}$ sodium bicarbonate $\left(\mathrm{NaHCO}_{3}\right), 50 \mathrm{mg} / \mathrm{L}$ hypoxanthine, $10 \mathrm{mg} / \mathrm{L}$ gentamicin, $10 \%$ heat-inactivated human serum, and red blood cells (RBCs) at a 3\% hematocrit in an atmosphere of $5 \% \mathrm{CO}_{2}, 5 \% \mathrm{O}_{2}$, and $90 \% \mathrm{~N}_{2}$ at $37{ }^{\circ} \mathrm{C}$ as previously described [25]. Ring-form parasites were collected using the sorbitol synchronization technique [26]. Briefly, the cultured parasites were collected by centrifugation at $840 \mathrm{~g}$ for $5 \mathrm{~min}$ at room temperature, suspended in a fivefold volume of $5 \%$ D-sorbitol (Nacalai Tesque, Kyoto, Japan) for $10 \mathrm{~min}$ at room temperature, and then they were washed twice with RPMI 1640 medium to remove the D-sorbitol. The utilization of blood samples of healthy Japanese volunteers for the parasite culture was approved by the institutional review committee of the Research Institute for Microbial Diseases (RIMD), Osaka University (approval number: 22-3).

\section{Antimalarial activity}

Ring-form-synchronized parasites were cultured with compounds $\mathbf{1}-\mathbf{2}$ at sequentially decreasing concentrations $(50,15,5,1.5,0.5,0.15,0.05$, and $0.015 \mu \mathrm{M})$ for $48 \mathrm{~h}$ for the flow cytometric analysis using an automated hematology analyzer, XN-30. The XN-30 analyzer was equipped with a prototype algorithm for cultured falciparum parasites (prototype; software version: 01-03, (build 16)) and used specific reagents (CELLPACK DCL, SULFOLYSER, Lysercell M, and Fluorocell M) (Sysmex, Kobe, Japan) $[27,28]$. Approximately $100 \mu \mathrm{L}$ of the culture suspension
Fig. 7 Plausible biogenetic pathway of $\mathbf{1}$ and $\mathbf{2}$

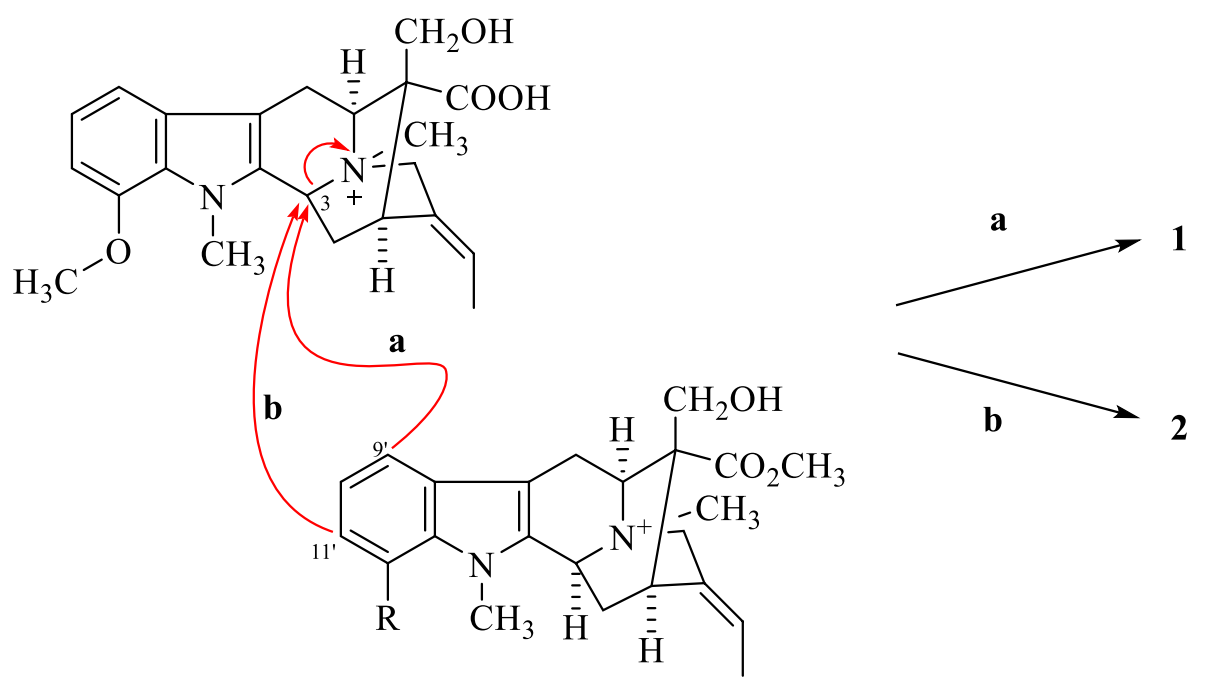

Sarpagine type

(12-methoxy-4-methylvoachalotine) (MMV)

1: $\mathrm{R}=\mathrm{OCH}_{3}$

2: $\mathrm{R}=\mathrm{OH}$ 
diluted with $100 \mu \mathrm{L}$ phosphate-buffered saline was added to a BD Microtainer MAP Microtube for Automated Process $\mathrm{K}_{2}$ EDTA $1.0 \mathrm{mg}$ tube (Becton Dickinson and Co., Franklin Lakes, NJ, USA) and loaded onto the XN-30 analyzer with an auto-sampler as described in the instrument manual (Sysmex). The parasitemia (MI-RBC\%) was automatically reported [27]. Then $0.5 \%$ DMSO alone or containing $5 \mu \mathrm{M}$ artemisinin was used as the negative and positive controls, respectively. The growth inhibition (GI) rate was calculated from the MI-RBC\% according to the following equation:

GI $(\%)=100-$ (test sample - positive control $) /($ negative control-positive control) $\times 100$.

The $\mathrm{IC}_{50}$ was calculated from GI (\%) using GraphPad Prism version 5.0 (GraphPad Prism Software, San Diego, CA, USA) [29].

Bisnaecarpamine A (1): yellowish amorphous solid. $[\alpha]_{\mathrm{D}}^{24}:-10(c 1.0, \mathrm{MeOH})$. IR $V_{\max }(\mathrm{KBr}): 3395$ and $1727 \mathrm{~cm}^{-1}$. UV/Vis $\lambda_{\max }(\mathrm{MeOH})(\log \varepsilon) 225$ (4.30), 271 (3.34) nm. CD $(\mathrm{MeOH}) \lambda_{\max }(\Delta \varepsilon) 229(-10.4)$ and 289 $(-0.57) \mathrm{nm} .{ }^{1} \mathrm{H}$ and ${ }^{13} \mathrm{C}$ NMR $\left(\mathrm{CD}_{3} \mathrm{OD}\right)$ : Table 1 . MS (ESI): $\mathrm{m} / \mathrm{z}: 733[\mathrm{M}]^{+}$. HRESIMS m/z: $733.4026[\mathrm{M}]^{+}$ (Calcd. for $\mathrm{C}_{44} \mathrm{H}_{53} \mathrm{~N}_{4} \mathrm{O}_{6}, 733.3960$ ).

Bisnaecarpamine $\mathrm{B}(2)$ : brownish amorphous solid. $[\alpha]_{\mathrm{D}}^{25}:-53\left(c\right.$ 1.0, MeOH). IR $V_{\max }(\mathrm{KBr}): 3386$ and $1725 \mathrm{~cm}^{-1}$. UV/Vis $\lambda_{\max }(\mathrm{MeOH})(\log \varepsilon) 225$ (4.66), 2.87 (4.12) nm. CD (MeOH) $\lambda_{\text {max }}(\Delta \varepsilon) 225(-20.8)$ and 287 $(-3.38) \mathrm{nm} .{ }^{1} \mathrm{H}$ and ${ }^{13} \mathrm{C}$ NMR $\left(\mathrm{CD}_{3} \mathrm{OD}\right)$ : Table 1 . MS (ESI): m/z: $719[\mathrm{M}]^{+}$. HRESIMS m/z: $719.3821[\mathrm{M}]^{+}$ (Calcd. for $\mathrm{C}_{43} \mathrm{H}_{51} \mathrm{~N}_{4} \mathrm{O}_{6}, 719.9025$ ).

\section{CD calculation}

The conformations were obtained using Monte Carlo analysis with MMFF94 force field and charges on Macromodel 9.1. CD calculations were performed in Turbomole 7.1 using RI-TD-DFT-B3LYP/SVPD level of theory on RIDFT-B3LYP/TZVP optimized geometries.

Supplementary Information The online version contains supplementary material available at https://doi.org/10.1007/s11418-021-01510-4.

\footnotetext{
Acknowledgements We thank to Prof. Masatsugu Kimura (Osaka City University, Osaka, Japan) for the kind gift of the 3D7 strain, Mr. Yuji Toya and Dr. Kinya Uchihashi (Sysmex, Kobe, Japan) for the setting of the XN-30 analyzer and Ms. Toshie Ishisaka and Ms. Sawako Itagaki for their technical assistance. We also thank to Centre for Plant Conservation Botanic Gardens, Bogor, Indonesia, for provide and determine the plant materials. This research was partially supported by the Ministry of Education, Culture, Sport, Science and Technology, Ministry of Religious Affairs (MoRA) of Indonesia by MoRA Scholarship for PA, Grants-in-Aid for Scientific Research [grant number JP19K07152] to $\mathrm{MH}$, and by Sysmex Corporation to TT.
}

\section{References}

1. Gunatilaka AAL (1999) Alkaloids from Sri Lankan flora. Alkaloids Chem Biol 52:1-101

2. Rahman MT, Tiruveedhula VVNPBNPB, Cook JM (2016) Synthesis of bisindole alkaloids from the Apocynaceae which contain a macroline or sarpagine unit: a review. Molecules 21:1525. https://doi.org/10.3390/molecules21111525

3. Jennings LK, Khan NMD, Kaur N, Rodrigues D, Morrow C, Boyd A, Thomas OP (2019) Brominated bisindole alkaloids from the celtic sea sponge Spongosorites calcicola. Molecules 24:3890

4. Zhang Y, Hu C (2020) Anticancer activity of bisindole alkaloids derived from natural sources and synthetic bisindole hybrids. Arch Pharm (Weinheim). https://doi.org/10.1002/ardp.202000092

5. Tang Y, Nugroho AE, Hirasawa Y, Tougan T, Horii T, Hadi AHA, Morita H (2019) Leucophyllinines A and B, bisindole alkaloids from Leuconotis eugeniifolia. J Nat Med 73:533-540. https://doi. org/10.1007/s11418-019-01297-5

6. Fadaeinasab M, Hadi AHA, Hoseinzadeh M, Morita H (2014) Indole alkaloids from Rauvolfia reflexa (Apocynaceae). Open Conf Proc J 5:21-23

7. Nugroho AE, Ono Y, Jin E, Hirasawa Y, Kaneda T, Rahman A, Kusumawati I, Tougan T, Horii T, Zaini NC, Morita H (2021) Bisindole alkaloids from Voacanga grandifolia Leaves. J Nat Med accepted. https://doi.org/10.1007/s11418-019-01297-5

8. Wong CP, Seki A, Horiguchi K, Shoji T, Arai T, Nugroho AE, Hirasawa Y, Sato F, Kaneda T, Morita H (2015) Bisleuconothine a induces autophagosome formation by interfering with AKTmTOR signaling pathway. J Nat Prod 78:1656-1662. https://doi. org/10.1021/acs.jnatprod.5b00258

9. Ahmad K, Hirasawa Y, Nugroho AE, Hadi AHA, Takeya K, Thomas NF, Awang K, Morita H, Ping TS, Nafiah MA (2013) New indole alkaloids from Kopsia singapurensis (RIDL.). Open Conf Proc J 4:75-82

10. Hirasawa Y, Dai X, Deguchi J, Hatano S, Sasaki T, Ohtsuka R, Nugroho AE, Kaneda T, Morita H (2019) New vasorelaxant indole alkaloids, taberniacins A and B, from Tabernaemontana divaricata. J Nat Med 73:627-632. https://doi.org/10.1007/ s11418-019-01293-9

11. Nugroho AE, Zhang W, Hirasawa Y, Tang Y, Wong CP, Kaneda T, Hadi AHA, Morita H (2018) Bisleuconothines B-D, modified eburnane-aspidosperma bisindole alkaloids from Leuconotis griffithii. J Nat Prod 81:2600-2604. https://doi.org/10.1021/acs.jnatp rod.8b00749

12. Hirasawa Y, Arai H, Rahman A, Kusumawati I, Zaini NC, Shirota O, Morita H (2013) Voacalgines A-E, new indole alkaloids from Voacanga grandifolia. Tetrahedron 69:10869-10875. https://doi. org/10.1016/j.tet.2013.10.097

13. Morita H, Haseo A, Eko Nugroho A, Hirasawa Y, Kaneda T, Shirota O, Rahman A, Kusumawati I, Cholies Zaini N (2015) A new indole alkaloid from Voacanga grandifolia. Heterocycles 1:601. https://doi.org/10.1002/chin.201521233

14. Ishizuka M, Koga I, Zaima K, Kaneda T, Hirasawa Y, Hadi AHA, Morita H (2013) Vasorelaxant effects on rat aortic artery by two types of indole alkaloids, naucline and cadamine. J Nat Med 67:399-403

15. Pratiwi DR, Bintang M, Simanjuntak P (2014) Lelutung tokak (Tabernaemontana macrocarpa Jack.) sebagai sumber zat bioaktif antioksidan dan antikanker. J Ilmu Kefarmasian Indones $12: 267-272$

16. Husain K, Said IM, Din LB, Takayama H, Kitajima M, Aimi N (1997) Alkaloids from the roots of Tabernaemontana macrocarpa Jack. Nat Prod Sci 3:42-48

17. Amelia P, Nugroho AE, Hirasawa Y, Kaneda T, Tougan T, Horii T, Morita H (2019) Two new sarpagine-type indole alkaloids and 
antimalarial activity of 16-demethoxycarbonylvoacamine from Tabernaemontana macrocarpa Jack. J Nat Med. https://doi.org/ 10.1007/s11418-019-01317-4

18. Parkanyi C, Bouin D, Aaron J-J, Villiers C (1983) Electronic absorption and fluorescence spectra of indole derivatives. quantitative treatment of the substituent effects and a theoretical study. Croat Chem Acta 56:157-168

19. Kutney JP (1977) Studies on the total synthesis of bisindole alkaloids in the vinblastine-vincristine series. Lloydia 40:107-126

20. Gonçalves MS, Curcino Vieira IJ, Oliveira RR, Braz-Filho R (2011) Application of preparative high-speed counter-current chromatography for the separation of two alkaloids from the roots of Tabernaemontana catharinensis (Apocynaceae). Molecules 16:7480-7487. https://doi.org/10.3390/molecules 16097480

21. Nugroho AE, Hirasawa Y, Kawahara N, Goda Y, Awang K, Hadi AHA, Morita H (2009) Bisnicalaterine A, a vobasinevobasine bisindole alkaloid from Hunteria zeylanica. J Nat Prod 72:1502-1506

22. Nugroho AE, Morita $H$ (2014) Circular dichroism calculation for natural products. J Nat Med 68:1-10. https://doi.org/10.1007/ s11418-013-0768-x

23. TURBOMOLE V7.1 (2009) A development of University of Karlsruhe and Forschungszentrum Karlsruhe GmbH, 1987-2007

24. Nugroho AE, Hirasawa Y, Piow WC, Kaneda T, Hadi AHA, Shirota O, Ekasari W, Widyawaruyanti A, Morita H (2012)
Antiplasmodial indole alkaloids from Leuconotis griffithii. J Nat Med 66:350-353. https://doi.org/10.1007/s11418-011-0574-2

25. Trager W, Jensen JB (1976) Human malaria parasites in continuous culture. Science 193:673 LP - 675. https://doi.org/10.1126/ science. 781840

26. Lambros C, Vanderberg JP (1979) Synchronization of Plasmodium falciparum erythrocytic stages in culture. J Parasitol 65:418-420

27. Tougan T, Suzuki Y, Itagaki S, Izuka M, Toya Y, Uchihashi K, Horii T (2018) An automated haematology analyzer XN-30 distinguishes developmental stages of falciparum malaria parasite cultured in vitro. Malar J 17:59. https://doi.org/10.1186/ s12936-018-2208-6

28. Toya Y, Tougan T, Horii T, Uchihashi K (2021) Lysercell M enhances the detection of stage-specific Plasmodium-infected red blood cells in the automated hematology analyzer XN-31 prototype. Parasitol Int 80:102206. https://doi.org/10.1016/j.parint. 2020.102206

29. Tougan T, Toya Y, Uchihashi K, Horii T (2019) Application of the automated haematology analyzer XN-30 for discovery and development of anti-malarial drugs. Malar J 18:8. https://doi.org/ 10.1186/s12936-019-2642-0

Publisher's Note Springer Nature remains neutral with regard to jurisdictional claims in published maps and institutional affiliations. 